\title{
Factors Underlying the Social and Cultural Capitals of High School Students and Their Relationship with English Achievement
}

\author{
Ebrahim Khodadady \\ Ferdowsi University of Mashhad, Iran \\ Email: ekhodadady@gmail.com \\ Farnaz Farokh Alaee \\ Ferdowsi University of Mashhad, Iran \\ Mottahareh Natanzi \\ Ferdowsi University of Mashhad, Iran
}

\begin{abstract}
This study explored the relationship between social and cultural capitals and English achievement by developing, administering and validating a 35-item questionnaire to 706 students of five public and private high school students in Mashhad, Iran. The application of the Principle Axis Factoring to the participants' responses and rotating the extracted factors revealed ten latent variables, i.e., family-school interaction, facility consciousness, extracurricular and religious activities, parental consultation, literary and artistic appreciation, family support, family-peer relation, reading enjoyment, family encouragement, and selfconfidence. No significant difference was found in the performance of private and public school students' scores on their final English examination. Neither the social and cultural capital questionnaire nor its ten extracted factors showed any significant relationship with the students' English achievement. However, when the performance of the students in private and public schools were analyzed separately and the items with low cross loading were removed from factors, a significant correlation was found between the second factor, i.e., facility consciousnesses, and the English achievement $(r=.12, p<.05)$ of public high school students. The implications of the results are brought up within a foreign language context and suggestions are made for future research.
\end{abstract}

Index Terms - cultural capital, social capital, foreign language, English achievement, factor analysis, cross loading

\section{INTRODUCTION}

Learning English as a foreign language requires many resources among which economic, cultural and social capitals stand out. While the first deal basically with the financial capabilities of individual members of a given society, the second depend on the attitudes they hold, activities they get involved and the information they gather from literature, music and art (see DiMaggio \& Mohr 1985). These attitudes, activities and pieces of information are also explored in various variables such as linguistic competence (Dumais 2002) and appropriate manners and good taste (De Graaf, 1986).

The third major sources required for foreign language learning are "the aggregate of actual or potential resources linked to possession of a durable network of essentially institutionalized relationships of mutual acquaintance and recognition" (Bourdieu 1986, p. 248). These sources which are owned by the whole society are then employed by its members as capitals and may in certain conditions be converted to economic capital.

There is general consensus that cultural capital is different from abilities such as GPA (e.g., Dumais 2002; Eitle and Eitle 2002, Farkas, Grobe, Sheehan, \& Shaun 1990; Kalmijn \& Kraaykamp 1996; Katsillis \& Rubinson 1992) as are economic and social capitals. Based on this difference a large number of studies have been designed to explore the relationship of these sources with variables such as persisting in school and educational attainment.

Wells (2008), for example, examined the effect of social and cultural capital on persistence from 1st to 2nd year. His study of 1,726 students showed student persistence has a positive association with social and cultural capitals. Persistence helped them overcome social barriers such as low family income, low parental education and the poor or illresourced schools.

As regards the relationship between social capital and educational attainment, Dika and Singh (2002) alone reviewed thirteen studies from 1991-2001. Furstenberg and Hughes (1995) and Yan (1999), for example, found a positive association between social capital, school graduation and college enrollment. Their results showed that parent-teen 
interactions, parents' expectations and encouragement and traditional family structure are positively related to the two educational outcomes.

Similarly, Bassani (2006) studied 2924 Japanese, 2135 US and 2364 Canadian 15-year-old students by employing the data collected by the Programme for International Student Assessment study from various countries and continents. They dealt with a large amount of information including students' families, schools and academic assessment. He found that $31 \%$ of the variation in American youths' math scores was explained by social resources while a smaller amount of variation was explained in the Canadian (20\%) and Japanese models (22\%).

The most recent study closely related to the present was done by Khodadady and Zabihi (2011) who explored the relationship between social and cultural capital with the grade point average (GPA) of high school diploma gained by 403 undergraduate and graduate Iranian university students who majored in Teaching English as a foreign language and Persian Language and Literature. Their findings will be compared with the present one because their questionnaire has been employed in the present study.

While most studies deal with the relationship between social and cultural capitals and school achievement in general (e.g., Bankston \& Caldas 1998; Eng 2009), GPA (e.g., Khodadady and Zabihi 2011) or particular subjects such as math (e.g., Bassani 2006), none have explored their relationship with English achievement in high schools in Mashhad. Although Khodadady and Zabihi's (2011) study deals with Iranian students in Mashhad, their sample has been drawn from university students whose GPA on their high school diploma has been associated with social and cultural capitals. The present study, however, addresses the relationship between the capitals and foreign language achievement in Mashhadi high schools. In particular, it attempts to answer the three questions below:

1. Will the scores of private high school students on their final English Examinations be significantly higher than their counterparts in public schools?

2. Will the total SCCQ and its social and cultural capital subscales correlate significantly with the participants' scores on their final English examination?

3. Will the factors extracted from the SCCQ correlate significantly with the participants' scores on their final English examination.

\section{METHODOLOGY}

\section{A. Participants}

Seven hundred and six female high school learners studying at grade 1, 2 and 3 participated in the present research. (Only female students took part in the project because the researchers' could not get access to boys' schools due to reasons beyond their control.) The questionnaires of ten students were, however, removed from analysis due to giving unreliable answers or not answering most items. Out of the remaining 696 students, 382 and 314 had enrolled in private and public high schools respectively. The participants' age ranged between 11 and 19 (Mean = 15.74, SD = 2.31). They all spoke Persian as their mother language.

\section{B. Instruments}

The social and cultural capital questionnaire (SCCQ) designed in this study consists of 35 items among which 11 deals with cultural capital and the remaining 24 concern social capital (see Appendix). The items were developed by Khodadady and Zabihi (2011) on the basis of the most frequently cited social and cultural capital indicators by Dika and Singh (2002) and Laureau and Weininger (2003). They translated the items into Persian and consulted at least two specialists in English translation and Persian language in order to ensure the validity of their translation and Persian style. The participants were required to read the Persian items one by one and indicate whether they had experienced the states or undertaken the actions brought up by each item on a six-point scale ranging from never to always. (The Persian translation is available upon request.)

The first item of the SCCQ, for example, read: I enjoy listening to classical music. After reading the statement, the participants had to specify whether they always, usually, often, sometimes, seldom or never enjoyed listening to classical music. The values $6,5,4,3,2$ and 1 were then assigned to each point to quantify the items.

In addition to the 35 items, four short questions were given at the beginning of the SCCQ to collect demographic information. They included the participants' field of study, gender, age, and their score on the final English examination. At the end of each session in which the questionnaires were distributed, the English teachers were consulted regarding the accuracy of the students' self-reported scores and there were only a few cases where the teacher had to check the official records to confirm the announced scores.

\section{Procedure}

There are 11 educational districts in Mashhad, the capital of Khorassan-e-Razavi province in Iran, i.e., 1, 2, 3, 4, 5, 6, and 7, Tabatkan, Kalat, Ahmadabad, and Razavieh. These eleven districts were divided into two upper and lower-class areas on the basis of information given by the Education Organization and two were chosen randomly as a convenient sample, i.e., district 4 and Tabatkan. Then from these two districts three private and two public high schools were chosen. The difference in the number of school types stems from the fact that private high schools in the two districts 
are distributed unequally. While there are many private schools in the well-to-do district four, there is only one in Tabatkan.

The private schools in the two educational districts charged different fees. Nour and Imam Reza high schools in district four, for example, charged 3,500,000 and 2,500,000 tomans annually, respectively, whereas Imam Reza High School in Tabatkan charged some 180,000 tomans. (1000 tomans was worth almost one American dollar at the time of research.) For this very sharp difference in tuition fees, some students living in district four had registered in the last school and were therefore commuting every day to attend the most affordable. The researchers attended all the schools in person and distributed the questionnaires while the students took part in their English classes. They were asked to write down the scores they got in their final English examination last year. The teachers were then consulted regarding the acceptability of the scores and whether they represented the students' English ability.

\section{Data Analysis}

The reliability of the social and cultural capital questionnaire (SCCQ) was estimated via SPSS version 16.0. Following Khodadady and Hashemi (2010), the principle axis factoring along with Varimax Rotation with Kaiser Normalization was employed to extract the rotated factors underlying the SCCQ. The students self-reported scores on their final English examination and the data obtained on the SCCQ were analysed to test the following hypotheses:

H1. The private school students' scores on final English examinations will be significantly higher than their counterparts in public schools.

H2. The total SCCQ and its logical social and cultural capital subscales will correlate significantly with the participants' scores on the final English examination.

H3. The factors extracted from the SCCQ will correlate significantly with the participants' scores on the final English examination.

\section{RESULTS AND DISCUSSION}

Table 1 presents the descriptive statistics related to the social and cultural capital questionnaire (SCCQ) developed by Khodadady and Zabihi (2011) and administered in this study. As can be seen, the total SCCQ enjoys a high reliability, i.e., .87, as does its social capital subscale, i.e., .84. The relatively moderate reliability of the cultural capital subscale, i.e., .73, is acceptable because it is almost half the length of the social capital subscale and thus its length has affected its reliability coefficient.

TABLE 1

DESCRIPTIVE STATISTICS OF THE SOCIAL CULTURAL CAPITAL QUESTIONNAIRE AND ITS SUBSCALES

\begin{tabular}{|l|l|l|l|l|l|}
\hline & N & \# of items & Mean & Std. Deviation & Alpha \\
\hline SCCQ & 696 & 11 & 137.56 & 25.097 & .87 \\
\hline Cultural Capital & 696 & 24 & 40.77 & 9.456 & .73 \\
\hline Social Capital & 696 & 35 & 96.79 & 19.131 & .84 \\
\hline
\end{tabular}

Table 2 presents the descriptive statistics of the scores obtained on final English examination. As can be seen, the mean score of public students (16.9) is slightly lower than that of private students (17.4). However, when an independent sample T-test was run on the scores obtained by the two groups no significant difference was found $(\mathrm{t}=1.455, \mathrm{df}=694, p<0.146)$. This finding thus disconfirmed the first hypothesis that the private school students' scores on final English Examinations will be significantly higher than their counterparts in public schools.

TABLE 2

DESCRIPTIVE STATISTICS OF THE SCORES OBTAINED ON FINAL ENGLISH EXAMINATION

\begin{tabular}{|l|l|l|l|l|}
\hline English Score & N & Mean & Std. Deviation & Std. Error Mean \\
\hline Private schools & 382 & 17.3545 & 4.15909 & .21280 \\
\hline Public Schools & 314 & 16.8992 & 4.04373 & .22820 \\
\hline
\end{tabular}

In order to determine what latent variables the SCCQ was measuring, the principle axis factoring was run. However, the Kaiser-Meyer-Olkin (KMO) measure of Sampling Adequacy was employed first to find out whether employing factor analysis to extract latent variables was appropriate. The KMO statistic obtained in this study was .87. According to Kaiser (1974) as cited in DiLalla and Dollinger (2006, p. 250), KMOs in the .80s is "meritorious," so the sample selected in this study was adequate for factorial analysis.

Table 3 presents the initial and extraction communalities obtained on the SCCQ. Initial communalities are estimates of the variance in each variable accounted for by all factors. Extraction communalities are, however, estimates of the variance in each variable accounted for by the factors in the factor solution. Martiniuk, Speechley, Secco and Campbell (2007) used extraction communalities to develop their questionnaire assessing children's knowledge and attitudes about epilepsy. Following Pett, Lackey and Sullivan (2003), they decided a priori that any items with extraction communalities below 0.2 would be dropped from their further analyses. 
TABLE 3

INITIAL AND EXTRACTION (EXT.) COMMUNALITIES OBTAINED ON SCCQ

\begin{tabular}{|l|l|l|l|l|l|l|l|l|l|l|l|}
\hline Item & Initial & Ext & Item & Initial & Ext & Item & Initial & Ext & Item & Initial & Ext \\
\hline 5 & .390 & .633 & 2 & .367 & .483 & 33 & .245 & .407 & 32 & .233 & .271 \\
\hline 27 & .435 & .611 & 31 & .363 & .475 & 15 & .328 & .386 & 16 & .163 & .252 \\
\hline 8 & .380 & .603 & 34 & .292 & .469 & 35 & .347 & .386 & 11 & .206 & .239 \\
\hline 30 & .482 & .585 & 17 & .317 & .467 & 12 & .289 & .358 & 14 & .199 & .231 \\
\hline 25 & .481 & .562 & 21 & .357 & .449 & 6 & .289 & .354 & 3 & .199 & .216 \\
\hline 29 & .504 & .562 & 18 & .280 & .426 & 4 & .248 & .349 & 19 & .192 & .209 \\
\hline 28 & .438 & .550 & 7 & .342 & .414 & 22 & .212 & .327 & 1 & .182 & .198 \\
\hline 23 & .500 & .531 & 10 & .331 & .412 & 26 & .301 & .307 & 20 & .118 & .149 \\
\hline 9 & .375 & .486 & 24 & .315 & .408 & 13 & .223 & .276 & & & \\
\hline
\end{tabular}

As can be seen in Table 3, only two items, i.e., 1 and 20, have extraction communalities below 0.20. This means that the remaining 33 items forming the SCCQ contributed to the factors extracted in this study. However, when principle axis factoring was applied to the items and the extracted factors were rotated by employing Varimax with Kaiser Normalization method, ten factors appeared upon which items 3, 19, 20, 26 and 32 did not load acceptably, i.e., 0.30 or higher, indicating that they do not contribute to social and cultural capitals enjoyed by the participants of the present study. Among the remaining 30 items, items 10, 23, 24, 29 and 35 cross loaded on at least two factors.

Table 4 presents the total variance explained by the ten factors extracted from the 35 items comprising the SCCQ. (The factors whose initial eigenvalues were lower than one have been deleted to save space.) As can be seen, the ten extracted factors explain $56.8 \%$ of variance in the whole questionnaire initially. However, when they were rotated, total variance explained by the ten factors decreased to $40.1 \%$.

TABLE 4

TOTAL VARIANCE EXPLAINED

\begin{tabular}{|l|l|l|l|l|l|l|}
\hline \multirow{2}{*}{ Factor } & \multicolumn{4}{|l|}{ Initial Eigenvalues } & \multicolumn{4}{l|}{ Extraction Sums of Squared Loadings } \\
\cline { 2 - 7 } & Total & \% of Variance & Cumulative \% & Total & \% of Variance & Cumulative \% \\
\hline 1 & 6.858 & 19.595 & 19.595 & 2.039 & 5.825 & 5.825 \\
\hline 2 & 2.389 & 6.827 & 26.422 & 1.960 & 5.600 & 11.425 \\
\hline 3 & 1.932 & 5.520 & 31.942 & 1.707 & 4.877 & 16.303 \\
\hline 4 & 1.657 & 4.733 & 36.675 & 1.547 & 4.420 & 20.722 \\
\hline 5 & 1.436 & 4.102 & 40.778 & 1.424 & 4.068 & 24.790 \\
\hline 6 & 1.238 & 3.538 & 44.316 & 1.281 & 3.659 & 28.450 \\
\hline 7 & 1.161 & 3.316 & 47.632 & 1.157 & 3.306 & 31.755 \\
\hline 8 & 1.119 & 3.197 & 50.829 & 1.132 & 3.236 & 34.991 \\
\hline 9 & 1.057 & 3.021 & 53.850 & 1.011 & 2.889 & 37.880 \\
\hline 10 & 1.030 & 2.943 & $\mathbf{5 6 . 7 9 3}$ & .782 & 2.234 & $\mathbf{4 0 . 1 1 4}$ \\
\hline
\end{tabular}

Extraction Method: Principal Axis Factoring.

As can be seen in Table 4, all the ten extracted values have the initial eigenvalues of one or higher. Kaiser (1958) suggested an eigenvalue of one to stop the process of extracting factors. However, some scholars suggest scree plots be employed to choose from among the extracted factors. In this approach the graph of eigenvalues is examined and the natural bend where the curve flattens out is spotted to retain only those factors which fall above the bend (e.g., Costello \& Osborne 2005).

Figures 1 presents the scree plot of extracted factors in this study whereas Figure 2 shows the components extracted by Martiniuk et al. (2007). While there is no natural bend discernable in the plot obtained in this study, the bend does appear at component three in Martiniuk et al's study. However, they adopted seven factors as underlying their 27-item questionnaire, indicating that they employed logic rather than the scree plot to determine the number of factors. Since Khodadady (2009) found a similar pattern when he compared the factors obtained in his study on the Beliefs about Language Learning Inventory with those of Hong (2006), it is suggested that instead of scree plots an eigenvalue of one be adopted as the cut off point to retain factors. 


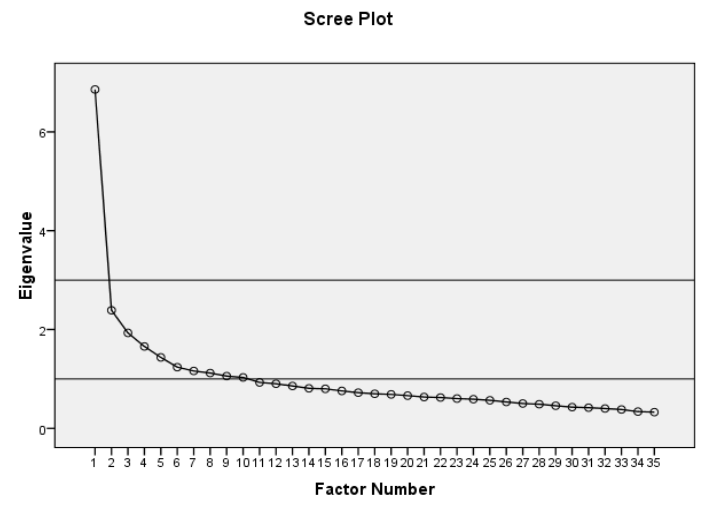

Figure 1. Scree plot of 10 extracted factors

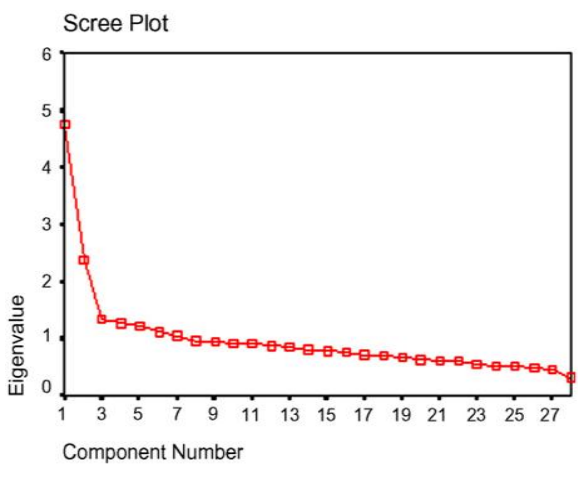

Figure 2. Scree plot of all Thinking about Epilepsy questionnaire items

The acceptance of ten factors on the basis of eigenvalues equal to one and higher is also supported by Khodadady and Zabihi's (2011) findings. Similar to the present study, they extracted ten factors when they applied principle component analysis to their data and rotated their extracted variables. In addition to yielding the same number of factors in two separate studies with different samples, the factors extracted in the present study highlight the exclusiveness of capitals which are logically different from the capitals to which they may contribute in studies with smaller samples.

Factor 10 in the present study, for example, consists of two items (see Table 14). Had the scree plot presented in Figure 1 had clear bend such as Figure 2, it would have been discarded in favour of the first two factors. However, item 2, I am highly proficient in using language, is logically different from all types of attitudes expressed in the SCCQ. It loads exclusively on factor ten as self-confidence and may explain the students' willingness to tell their parents where they are and what they do as the second variable which cross loads on factors one, family-school interaction, and four, parental consultation show they do.

Table 5 presents the rotated loadings of six items, i.e., 12, 18, 23, 24, 25 and 29, on the first factor called familyschool interaction in this study. Out of $40.1 \%$, this factor explains 5.8 percent of variance in the loadings. As can be seen, item 18, i.e., My mom used to attend school meetings regularly, has the highest loading on the factor, i.e., .62. Among the six items comprising the first factor, two items cross load on factors 4, 6, and 10.

TABLE 5

ITEMS LOADING ON THE FIRST FACTOR OF FAMILY-SCHOOL INTERACTION

\begin{tabular}{|l|l|l|l|}
\hline No & Items & Loading & Crossloading \\
\hline 18 & My mom used to attend school meetings regularly. & .615 & - \\
\hline 25 & My parents used to have a regular connection with my school. & .600 & - \\
\hline 12 & My mother used to get involved in my primary schooling. & .553 & - \\
\hline 29 & My parents used to monitor my homework regularly. & .491 & $6(.398)$ \\
\hline 23 & At home, my parents keep track of my progress. & .390 & - \\
\hline 24 & My parents know where I am, what I do. & .307 & $4(.379) 10(.365)$ \\
\hline
\end{tabular}

While the first factor in this study relates to family-school interaction, it is literacy in Khodadady and Zabihi's (2011) study on which item 8 , I enjoy reading (in general), has the highest loading, i.e., .73. Along with items 2, 5, and 7, literacy explains $6.3 \%$ out of $47.7 \%$ of variance in all loadings in their study. The findings obtained in this study along with those of Khodadady and Zabihi emphasize the importance of validating the SCCQ with specific populations in order to find out what factors underlie their cultural and social capitals. If the parents of these high school students wish their children to enter universities they need to gear their school interactions towards literacy.

Table 6 presents the rotated loadings of six items, i.e., 4, 6, 10, 11, and 21, on the second factor called facility consciousness in this study. Out of $40.1 \%$, this factor explains 5.6 percent of variance in the loadings. As can be seen, item 21, i.e., I had excellent schools with high quality, has the highest loading on the factor, i.e., .57. Among the five items comprising the second factor, only item ten cross loads on factor nine.

TABLE 6

ITEMS LOADING ON THE SECOND FACTOR OF FACILITY CONSCIOUSNESS

\begin{tabular}{|l|l|l|l|}
\hline No & Items & Loading & Crossloading \\
\hline 21 & I had excellent schools with high quality. & .573 & - \\
\hline 4 & I know all famous music composers. & .561 & - \\
\hline 6 & I frequently visit museums and theaters. & .492 & - \\
\hline 11 & I used to take or art or music classes outside school. & .444 & - \\
\hline 10 & We have lots of books at home. & .385 & $9(.395)$ \\
\hline
\end{tabular}


Table 7 presents the rotated loadings of four items, i.e., 13, 14, 27 and 28, on the third factor called extracurricular and religious activities in this study. Out of $40.1 \%$, this factor explains 4.9 percent of variance in the loadings. As can be seen, item 27, i.e., I used to participate in school activities regularly, has the highest loading on the factor, i.e., .74. None of the items forming factor three cross loads on other factors.

TABLE 7

ITEMS LOADING ON THE THIRD FACTOR OF EXTRACURRICULAR AND RELIGIOUS ACTIVITIES

\begin{tabular}{|l|l|l|l|}
\hline No & Items & Loading & Crossloading \\
\hline 27 & I used to participate in school activities regularly. & .737 & - \\
\hline 28 & I used to participate in extracurricular activities. & .660 & - \\
\hline 13 & I like to get involved in activities designed for young people. & .462 & - \\
\hline 14 & I usually get involved in religious activities in mosques. & .334 & - \\
\hline
\end{tabular}

Table 8 presents the rotated loadings of four items, i.e., 24, 30, 31 and 35, on the fourth factor called parental consultation in this study. Out of $40.1 \%$, this factor explains 4.4 percent of variance in the loadings. As can be seen, item 30, i.e., I usually talk about job/education with family, has the highest loading on the factor, i.e., .61. Items 24 and 35 cross load on factors ten and seven, respectively.

TABLE 8

ITEMS LOADING ON THE FOURTH FACTOR OF PARENTAL CONSULTATION

\begin{tabular}{|l|l|l|l|}
\hline No & Items & Loading & Crossloading \\
\hline 30 & I usually talk about job/education with family. & $\mathbf{. 6 1 3}$ & - \\
\hline 31 & I usually talk about job/education with other adults. & .585 & - \\
\hline 24 & My parents know where I am, what I do. & .379 & $10(.365)$ \\
\hline 35 & We have an intimate home environment. & .353 & $7(.312)$ \\
\hline
\end{tabular}

Table 9 presents the rotated loadings of three items, i.e., 1, 2, and 5, on the fifth factor called literary and artistic appreciation in this study. Out of $40.1 \%$, this factor explains 4.1 percent of variance in the loadings. As can be seen, item 5, i.e., I know a lot about literature, has the highest loading on the factor, i.e., .73. None of the items forming factor five cross loads on other factors.

TABLE 9

ITEMS LOADING ON THE FIFTH FACTOR OF LITERARY AND ARTISTIC APPRECIATION

\begin{tabular}{|l|l|l|l|}
\hline No & Items & Loading & Crossloading \\
\hline 5 & I know a lot about literature. & .730 & - \\
\hline 2 & I enjoy reading literature. & .660 & - \\
\hline 1 & I enjoy listening to classical music. & .348 & - \\
\hline
\end{tabular}

Table 10 presents the rotated loadings of three items, i.e., 15, 16, and 17, on the sixth factor called family support in this study. Out of $40.1 \%$, this factor explains 3.7 percent of variance in the loadings. As can be seen, item 17, i.e., $M y$ parents used to help me with my homework regularly, has the highest loading on the factor, i.e., .61. None of the items forming factor six cross loads on other factors.

TABLE 10

ITEMS LOADING ON THE SIXTH FACTOR OF FAMILY SUPPORT

\begin{tabular}{|l|l|l|l|}
\hline No & Items & Loading & Crossloading \\
\hline 17 & My parents used to help me with my homework regularly. & .614 & - \\
\hline 15 & My parents usually get involved in my daily activities. & .434 & - \\
\hline 16 & I see my grandparents weekly. & .424 & - \\
\hline
\end{tabular}

Table 11 presents the rotated loadings of three items, i.e., 33, 34, and 35, on the seventh factor called family-peer relation in this study. Out of $40.1 \%$, the fifth factor explains 3.3 percent of variance in the loadings. As can be seen, item 34, i.e., My parents have strong ties with each other, has the highest loading on factor seven, i.e., .61. Among the three items comprising factor seven, item 35 cross loads on factor four.

TABLE 11

ITEMS LOADING ON THE SEVENTH FACTOR OF FAMILY-PEER RELATION

\begin{tabular}{|l|l|l|l|}
\hline No & Items & Loading & Crossloading \\
\hline 34 & My parents have strong ties with each other. & .610 & - \\
\hline 33 & I feel I have strong ties with my peers. & .598 & - \\
\hline 35 & We have an intimate home environment. & .312 & $4(.353)$ \\
\hline
\end{tabular}

Table 12 presents the rotated loadings of two items, i.e., 7 and 8, on the eighth factor called reading enjoyment in this study. Out of $40.1 \%$, the eighth factor explains 3.2 percent of variance in the loadings. As can be seen, item 8 , i.e., $I$ enjoy reading (in general), has the highest loading on factor four, i.e., .70. The other item comprising factor eighth does not cross load on any other factor. 
TABLE 12

ITEMS LOADING ON THE EIGHTH FACTOR OF READING ENJOYMENT

\begin{tabular}{|l|l|l|l|}
\hline No & Items & Loading & Crossloading \\
\hline 8 & I enjoy reading (in general). & .701 & - \\
\hline 7 & I frequently borrow/buy books. & .528 & - \\
\hline
\end{tabular}

Table 13 presents the rotated loadings of two items, i.e., 9 and 10, on the ninth factor called family encouragement in this study. Out of $40.1 \%$, the ninth factor explains 2.9 percent of variance in the loadings. As can be seen, item 9 , i.e., When a child, my parents regularly encouraged me to read, has the highest loading on factor ninth, i.e., .53. The other item comprising factor nine cross loads on factor two.

TABLE 13

ITEMS LOADING ON THE NINTH FACTOR OF FAMILY ENCOURAGEMENT

\begin{tabular}{|l|l|l|l|}
\hline No & Items & Loading & Crossloading \\
\hline 9 & When a child, my parents regularly encouraged me to read. & .525 & - \\
\hline 10 & We have lots of books at home. & .395 & $2(.385)$ \\
\hline
\end{tabular}

Table 14 presents the rotated loadings of two items, i.e., 22 and 24, on the tenth factor called self-confidence in this study. Out of $40.1 \%$, the eighth factor explains 2.2 percent of variance in the loadings. As can be seen, item 22 , i.e., $I$ am highly proficient in using language, has the highest loading on factor ten, i.e., .49. The other item comprising factor ten cross loads on factors one and four.

TABLE 14

ITEMS LOADING ON THE TENTH FACTOR OF SELF-CONFIDENCE

\begin{tabular}{|l|l|l|l|}
\hline No & Items & Loading & Crossloading \\
\hline 22 & I am highly proficient in using language. & .492 & - \\
\hline 24 & My parents know where I am, what I do. & .365 & $1(.307) 4(.379)$ \\
\hline
\end{tabular}

Table 15 presents the correlations between the participants' score on final English examination and the SCCQ, its cultural capital and social capital subscales and ten extracted factors. As can be seen, the results disconfirm the second hypothesis that the total SCCQ and its logical social and cultural capital subscales will correlate significantly with the participants' scores on the final English examination.

TABLE 15

CORRELATIONS BETWEEN THE PARTICIPANTS' SCORE ON FINAL ENGLISH EXAMINATION AND THE SCCQ, ITS CULTURAL CAPITAL AND SOCIAL CAPITAL SUBSCALES AND TEN EXTRACTED FACTORS

\begin{tabular}{|c|c|c|c|c|c|c|c|c|c|c|c|c|c|}
\hline \multirow{2}{*}{$\begin{array}{l}\text { Participants' } \\
\text { Score in }\end{array}$} & \multirow{2}{*}{ SCCQ } & \multicolumn{2}{|c|}{ Subscales } & \multicolumn{10}{|c|}{ Factors (with cross loading) } \\
\hline & & Cultural & Social & 1 & 2 & 3 & 4 & 5 & 6 & 7 & 8 & 9 & 10 \\
\hline Both schools & .045 & .066 & .027 & .011 & .035 & .029 & .039 & .062 & -.032 & .040 & .050 & .022 & -.012 \\
\hline Private schools & -.026 & .022 & -.043 & -.029 & -.060 & -.014 & -.034 & .093 & -.092 & .042 & .022 & -.030 & -.069 \\
\hline \multirow[t]{2}{*}{ Public schools } & .104 & .092 & .092 & .031 & .104 & .071 & .099 & .010 & .025 & .018 & .073 & .056 & .047 \\
\hline & & & & \multicolumn{10}{|c|}{ Factors (without cross loading) } \\
\hline Both schools & .045 & .066 & .027 & .016 & .041 & .029 & .039 & .062 & -.032 & .034 & .050 & .022 & .002 \\
\hline Private schools & -.026 & .022 & -.043 & -.027 & -.055 & -.014 & -.034 & .093 & -.092 & .062 & .022 & -.030 & -.081 \\
\hline Public schools & .104 & .092 & .092 & .038 & $.118 *$ & .071 & .099 & .010 & .025 & -.015 & .073 & .056 & .088 \\
\hline
\end{tabular}

When the ten extracted factors were correlated with the participants' scores on the final English examination, only factor two whose crossloading items were removed showed a significant correlation with the scores obtained by public high school students, i.e., $\mathrm{r}=.12 \mathrm{p}<.05$ (see Table 15). These results disconfirm the third hypothesis that the factors extracted from the SCCQ will correlate significantly with the participants' scores on the final English examination. They, therefore, challenge the research findings showing that social capital influences children's educational outcomes irrespective of their socioeconomic status (McNeal 1999; Sun 1999; Zhou \& Bankston 1996).

The findings of this study are in sharp contrast to those found by Khodadady and Zabihi (2011). The ninth factor in this study, i.e., family encouragement, did not show any significant relationship with English achievement, however, as the seventh factor in Khodadady and Zabihi's study it had the highest significant correlation coefficient with the participants' GPA on their high school diploma $(\mathrm{r}=.33 \mathrm{p}<.01)$, indicating that about eleven percent of GPA obtained by former high school students who entered Iranian universities is explained by their family encouragement alone.

Considering the fact that out of 403 students participating in Khodadady and Zabihi's (2011) study 230 (57\%) were studying English language and literature at undergraduate and graduate levels at Ferdowsi University of Mashhad and Mashhad Azad University, the lack of any significant relationship between English achievement and factors like family encouragement may be employed to highlight either the irrelevance of teaching English in high schools or inadequacy of assessing English achievement by language teachers. Future research must show whether holding independent 
achievement tests by researchers will result in establishing significant relationships between English achievement and social and cultural capitals.

\section{CONCLUSIONS}

This study identified ten latent variables underlying the 35-item social and cultural capital questionnaire (SCCQ), i.e., family-school interaction, facility consciousness, extracurricular and religious activities, parental consultation, literary and artistic appreciation, family support, family-peer relation, reading enjoyment, family encouragement, and selfconfidence. Half of these factors deal with the relationship among family members and support they get from each other, emphasizing the fact that families should be taken into serious consideration by the educational authorities and policy makers.

The Iranian society in general and the population in Mashhad in particular is going through a rapid change in which the number of mothers entering the job market is increasing in order to keep up with ever-increasing expenses, and in the case of education, to help pay the tuition fees charged by private high schools. If the mothers lack the qualifications or do not wish to get into the job market, the fathers have to work more and thus spend less time with the children. Unfortunately, there is no study available right now to compare the results of this study with, say, 30 years ago, they can, nonetheless, be used in future to trace changes the families in Mashhad go through over time in order to cope with economic and educational factors and how these changes may affect the factors underlying social and cultural capitals.

Among the ten factors, only factor two, facility consciousness, showed a significant relationship with the public school students' scores on final English examination, indicating that the more high quality public schools parents choose, the better their children learn English as a foreign language. These children extend their learning of English to arts, music and attending museums and theatres and thus become more broad minded as compared to their peers in private high schools.

In this study no significant relationship was found between the SCCQ, its subscales and its nine underlying factors because its sample was relatively small. While Beaulieu, Israel, Hartless and Dyk (2001), for example, employed a stratified national probability sample of over 1,052 schools from which they collected a total of 24,599 usable responses from just eighth graders, the present study could have access to only 706 ninth, tenth and eleventh graders. It is therefore suggested that this study be replicated with certain graders, such as eighth only.

It is also recommended that the number of items comprising the SCCQ be increased so that more social and cultural indicators can be addressed. For example, this study did not explore whether the participants' parents limit their TV and internet time. And finally, it seems employing an independent measure such schema-based cloze multiple choice item tests developed on the English textbooks taught at a given grade or a language proficiency test might provide a more effective index to explore the relationship between school achievement in foreign language and social and cultural capitals.

\section{APPENDIX}

Social and Cultural Capital Questionnaire

\begin{tabular}{|c|c|c|c|c|c|c|c|}
\hline NO & Statement & Always & Usually & Often & sometimes & Seldom & Never \\
\hline 1 & I enjoy listening to classical music. & & & & & & \\
\hline 2 & I enjoy reading literature. & & & & & & \\
\hline 3 & I am a cultured person. & & & & & & \\
\hline 4 & I know all famous music composers. & & & & & & \\
\hline 5 & I know a lot about literature. & & & & & & \\
\hline 6 & I frequently visit museums and theaters. & & & & & & \\
\hline 7 & I frequently borrow/buy books. & & & & & & \\
\hline 8 & I enjoy reading (in general). & & & & & & \\
\hline 9 & When a child, my parents regularly encouraged me to read. & & & & & & \\
\hline 10 & We have lots of books at home. & & & & & & \\
\hline 11 & I used to take or art or music classes outside school. & & & & & & \\
\hline 12 & My mother used to get involved in my primary schooling. & & & & & & \\
\hline 13 & I like to get involved in activities designed for young people. & & & & & & \\
\hline 14 & I usually get involved in religious activities in mosques. & & & & & & \\
\hline 15 & My parents usually get involved in my daily activities. & & & & & & \\
\hline 16 & I see my grandparents weekly. & & & & & & \\
\hline 17 & My parents used to help me with my homework regularly. & & & & & & \\
\hline 18 & My mom used to attend school meetings regularly. & & & & & & \\
\hline 19 & I feel I have a strong help network for my activities. & & & & & & \\
\hline 20 & I see my friends weekly. & & & & & & \\
\hline 21 & I had excellent schools with high quality. & & & & & & \\
\hline 22 & I am highly proficient in using language. & & & & & & \\
\hline 23 & At home, my parents keep track of my progress. & & & & & & \\
\hline 24 & My parents know where I am, what I do. & & & & & & \\
\hline 25 & My parents used to have a regular connection with my school. & & & & & & \\
\hline 26 & My parents know parents of my friends. & & & & & & \\
\hline
\end{tabular}




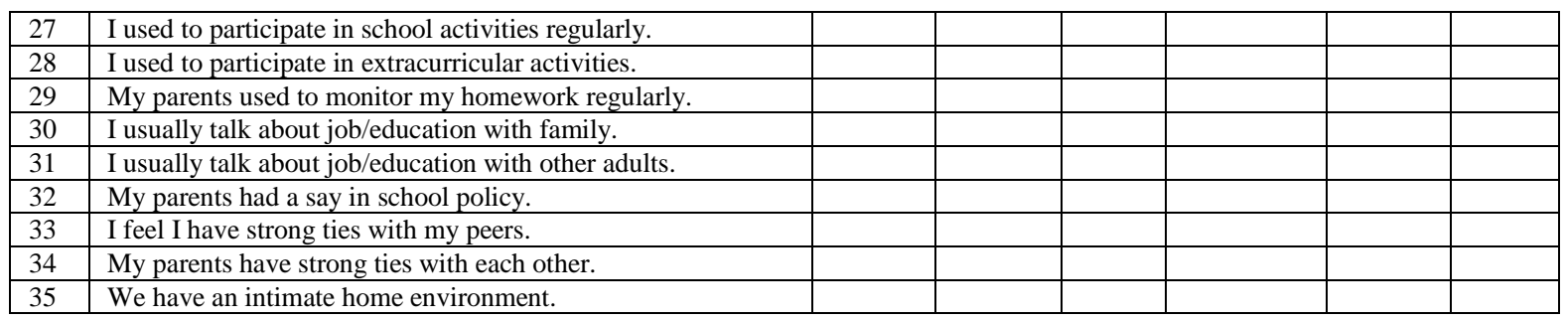

\section{REFERENCES}

[1] Bankston, C., \& Caldas, S. (1998). Family structure, schoolmates and racial inequalities in school achievement. Journal of Marriage and the Family, 60(3), 715-723.

[2] Bassani, C. (2006). A test of social capital theory outside of the American context: Family and school social capital and youths' math scores in Canada, Japan, and the United States. International Journal of Educational Research, 45(6), 380-403.

[3] Beaulieu, L. J., Israel, G. D., Hartless, G., \& Dyk, P. (2001). For whom does the school bell toll? Multi-contextual presence of social capital and student educational achievement. Journal of Socio-Economics, 30, 121-127.

[4] Bourdieu, P. (1986). The forms of capital, in J. G. Richardson (ed.). Handbook for Theory and Research for the Sociology of Education, 241-258. New York: Greenwood.

[5] Coleman, J. S. (1988). Social capital in the creation of human capital. American Journal of Sociology, 94, S95-S120.

[6] Cook-Gumperz, J. (1986). The social construction of literacy. Cambridge, UK: Cambridge University Press.

[7] Costello, A. B. \& Osborne, J. W. (2005). Best practices in exploratory factor Analysis: Four recommendations for getting the most from your analysis. Practical Assessment Research \& Evaluation, 10/ 7, 1-9. Retrieved January 27, 2009 from http://pareonline.net/pdf/v10n7.pdf.

[8] De Graaf, P. (1986). The impact of financial and cultural resources on educational attainment in the Netherlands. Sociology of Education, 59, 237-246.

[9] Dika, S. L., Singh, K. (2002). Applications of social capital in educational literature: A critical synthesis. Review of Educational Research, 72 (1), 31-60.

[10] DiLalla, D. L., \& Dollinger, S. J. (2006). Cleaning up data and running preliminary analyses. In F. T. L. Leong and J. T. Austin (Ed.). The psychology research handbook: A guide for graduate students and research assistants (241-253). California: Sage.

[11] DiMaggio P. (1982). Cultural capital and school success. American Sociological Review, 47, 189-201.

[12] DiMaggio, P., \& Mohr, J. (1985). Cultural capital, educational attainment, and marital selection. American Journal of Sociology, 90, 1231-1261.

[13] Dumais, S. A. (2002). Cultural capital, gender, and school success: The role of habitus. Sociology of Education 75, 44-68.

[14] Eng, S. (2009). Social capital and academic achievement among children in Cambodia: A close look at family. Unpublished doctoral dissertation, Texas Tech University.

[15] Eitle, T. M., Eitle, D. (2002). Race, cultural capital, and the educational effects of participation in sports. Sociology of Education 75, 123-146.

[16] Farkas, G., Grobe, R., Sheehan, D., \& Shuan, Y. (1990). Cultural resources and school success: Gender, ethnicity, and poverty groups within an urban district. American Sociological Review 55, 127-142.

[17] Furstenberg, F., \& Hughes, M. (1995). Social capital and successful development among at-risk youth. Journal of Marriage and the Family, 57(3), 580-592.

[18] Hong, K. (2006). Beliefs about language learning and language learning strategy use in an EFL context: a comparison study of monolingual Korean and bilingual Korean-Chinese university students. Unpublished doctoral dissertation, University of North Texas.

[19] Kaiser, H. (1958). The varimax criterion for analytic rotation in factor analysis. Psychometrika, 23, 187-200.

[20] Kaiser, H. (1974). An index of factorial simplicity. Psychometrika, 39, 31-6.

[21] Kaiser, H. F. \& Rice, J. (1974). Little Jiffy, Mark IV. Educational and Psychological Measurement, 34, 111-117

[22] Kalmijn, M., \& Kraaykaamp, G. (1996). Race, cultural capital, and schooling: An analysis of trends in the United States. Sociology of Education 69, 22-34

[23] Kastillis, K., \& Rubinson, R. (1990). Cultural capital, student achievement, and educational reproduction. American Sociological Review 55, 270-279.

[24] Khodadady, E. (2009).The beliefs about language learning inventory: Factorial validity, formal education and the academic achievement of Iranian students majoring in English. Iranian Journal of Applied Linguistics (IJAL), 12 (1), 115-165.

[25] Khodadady, E., \& Hashemi, M. R. (2010). Construct validity of beliefs about language learning: Componential or factorial. Ferdowsi Review, 1(1), 3-20.

[26] Khodadady, E., \& Zabihi, R. (2011). Social and cultural capital: Underlying factors and their relationship with the school achievement of Iranian university students. International Education Studies, 4(2), 63-71. doi:10.5539/ies.v4n2p63.

[27] Lareau, A., \& Weininger, E. B. (2003). Cultural capital in educational research: A critical assessment. Theory and Society, 32, 567-606.

[28] Martiniuk, A. L., Speechley, K, N., Secco, M., \& Campbell, M. K. (2007). Development and psychometric properties of the thinking about epilepsy questionnaire assessing children's knowledge and attitudes about epilepsy. Epilepsy \& Behavior, 10, $595-603$.

[29] McNeal, R. B. (1999). Parental involvement as social capital: Differential effectiveness on science achievement, truancy, and dropping out. Social Forces, 78(1), 117-144. 
[30] Pett, M. A, Lackey N. R. , \& Sullivan, J. J. (2003). Making sense of factor analysis: the use of factor analysis for instrument development in health care research. Thousand Oaks, CA: Sage.

[31] Portes, A. (2000).The two meanings of social capital. Sociological Forum, 15(1), 1-1 2.

[32] Sun, Y. (1999). The contextual effects of community social capital on academic performance. Social Science Research, 28, 403-426.

[33] Wells, R. (2008). The effects of social capital and cultural capital on student persistence. Community College Review, 25-46.

[34] Yan, W. (1999). Successful African American students: The role of parental involvement. Journal of Negro Education, 68(1), $5-22$.

[35] Zhou, M. \& Bankston, C. L. (1996). Social capital and the adaptation of the second generation: the case of Vietnamese youth in New Orleans. In A. Portes (Ed.). The New Second Generation (197-220). New York: Russell Sage Foundation.

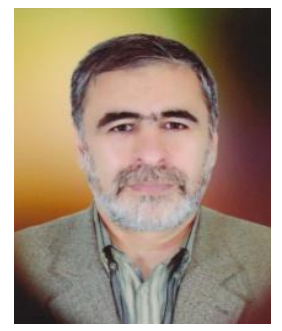

Ebrahim Khodadady was born in Iran in 1958. He obtained his $\mathrm{PhD}$ in Applied Linguistics from the University of Western Australia in 1998. He holds TESL Ontario and Canadian Language Benchmarks Placement Test (CLPBPT) certificates and has taught English as a first, second and foreign language to high school and university students in Australia, Canada and Iran.

$\mathrm{He}$ is currently an academic member of English Language and Literature Department at Ferdowsi University of Mashhad, Iran. He was invited as a VIP by Brock University in Canada in 2004 and served as the Associate Director of Assessment Center at George Brown College in Toronto for almost a year. His published books are Multiple-Choice Items in Testing: Practice and Theory (Tehran, Rahnama, 1999), Reading Media Texts: Iran-America Relations (Sanandaj, Kurdistan University, 1999) and English Language Proficiency Course: First Steps (Sanandaj, Kurdistan University, 2001). His main research interests are Testing, Language Learning and Teaching.

Dr. Khodadady is currently a member of Teaching English Language and Literature Society of Iran (TELLSI), TESL Ontario and European Society for Translation Studies. He is on the editorial board of Ferdowsi Review: An Iranian Journal of TESL, Literature and Translation Studies and has reviewed some research papers for Iranian Journal of Applied Linguistics and TESL Canada Journal as a guest reviewer.

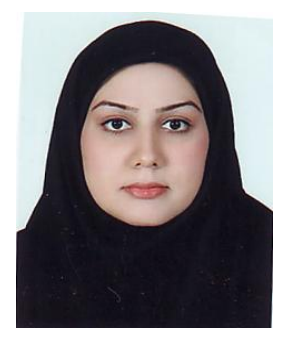

Farnaz Farrokh Alaee was born in Iran in 1978. She obtained her B.A in TEFL (Teaching English as a Foreign Language) as a top student from Azad University of Mashhad in 2000. She has also obtained in the same position in her MA studies at Ferdowsi University of Mashhad, Iran and her joint paper on "Generic Analysis of Informal Internet-based Chat between Iranian EFL teenagers and foreigners" is under review.

She has taught English as a foreign language in different private institutes and schools in Mashhad to different levels. Now she is working on her M.A thesis under the title of "Designing and Validating a Social Capital Questionnaire: Exploring the Relationship between Social Capital and Language Achievement in a Specific Foreign Language Context" supervised by Dr. Khodadady, an academic member of Ferdowsi University.

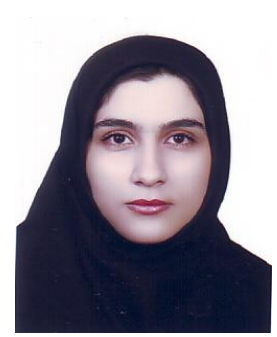

Motahareh Natanzi was born in Iran in 1987. She obtained her B.A in Teaching English as a Foreign Language (TEFL) from Azad University of Mashhad in 2006. She is currently an MA student of TEFL in Ferdowsi University of Mashhad and her joint paper on "Generic Analysis of Informal Internet-based Chat between Iranian EFL teenagers and foreigners" is under review.

She has taught TEFL at all proficiency levels in different institutes and private schools of Mashhad. She is presently working on her M.A thesis on "Designing and Validating a Cultural Capital Questionnaire and Exploring the Relationship between Cultural Capital and Language Proficiency." 